\title{
Heavy metal uptake by plants from wastewater of different pulp concentrations and contaminated soils
}

\author{
Saeed Shojaei ${ }^{1 *}$, Amir Jafarpour ${ }^{2}$, Siroos Shojaei ${ }^{3}$, Yeboah Gyasi-Agyei $^{4}, J^{2}$ sús Rodrigo- \\ Comino 5,6 \\ 1. Department of Management the Arid and Desert Regions, College of Natural Resources and Desert, Yazd \\ University, Yazd, Iran \\ 2. Faculty of Mining and Metallurgy, Yazd University, Yazd. Iran \\ 3. Department of Chemistry, University of Sistan and Baluchestan, Zahedan, Iran \\ 4. School of Engineering and Built Environment, Griffith University, Nathan, Queensland, 4111, Australia \\ 5. Soil Erosion and Degradation Research Group, Department of Geography, University of Valencia, \\ 46010 Valencia, Spain \\ 6. Physical Geography, Trier University, 54286 Trier, Germany \\ *Corresponding author Email $\underline{\mathrm{S} \_ \text {shojaei@ut.ac.ir }}$
}

\begin{abstract}
There is a lack of information on the extent of mineral extraction by plants from wastewater in arid and semi-arid environments in developing countries. This research assesses the performance of Alhagi and Mallow plant species for the absorption of heavy metals around the tailings dam of a copper mine in Iran. The industrial wastewater, known as the pulp, from the copper mine site has different concentrations of heavy metals. In a laboratory setting the plants were cultivated and irrigated with different pulp concentrations $(0,20,40,60,80$, and $100 \%)$ in water. Heavy metals (chromium, manganese, cadmium, and lead) accumulation in the aerial parts and roots of the plants, and the in-situ soil around the tailings dam, were measured using an atomic absorption spectrometer. Soil mapping based on geostatistical methods was also conducted to show the spatial pattern of the contaminants in the surrounds of the tailings dam. Our results demonstrated that heavy metals accumulation was higher in the roots than in the aerial parts, and chromium and
\end{abstract}


cadmium uptake by the Alhagi plant was higher than by the Mallow. The soil mapping showed that cadmium, lead and manganese had a higher dispersion compared to chromium, a high percentage being concentrated in some hotspots. Alhagi and Mallow plants, therefore, have a high potential to remediate heavy metal contaminated areas around the tailings dam and are recommended for widespread use. However, frequent plant harvesting should be encouraged to help reduce the migration of heavy metals from the contaminated soils into the surrounding environment. This research contributes to cleaner industrial production in non-developing and developing countries.

Keywords: pulp concentration; soil contamination; heavy metal absorption; soil mapping; cleaner production.

\section{Introduction}

Human activities, such as mining, are putting pressure on the natural ecosystems that lead to land and environmental degradation (Acín-Carrera et al., 2013). This environmental crisis is occurring because of the increasing non-sustainable exploitation of the land that also causes damage to the health of specific vulnerable humans (Stindt, 2017). Industrial and urban areas, considered to be indicators of development, have always registered the maximum pollution indexes, although agricultural areas are also very vulnerable to contamination (Li et al., 2017) and other processes such as erosion, loss of fertility or biodiversity (Hietala-Koivu et al., 2004; Moreno 
et al., 2007; Rodrigo-Comino et al., 2020). Lack of environmental compliance in the development of mineral and industrial activities, especially in developing countries, has caused a high volume of pollutants in water, air and land (Bandala and Rodriguez-Narvaez, 2019).

Human health, food safety, industrial development, and ecological systems are under threat due to environmental contamination by human activities (Shelton et al., 2002: Rosa et al., 2019). Management of wastewater caused by the production process is a vital issue to be investigated in the mineral and industrial establishments (Lin et al., 2020). Sustainable development involving the management of wastewater and environmental pollution needs to be assessed and mitigation measures proposed to combat the negative impacts of human activities (Sangwan and Bhatia, 2020). At many mining and industrial sites, the most commonly used method to assess the environmental impact is the collection of soil and plant samples in tailings dams for the study of heavy metal uptake by plants and pollution dispersion caused by wastewater. Some pioneering studies focused on the use of plants in treating polluted water (e.g., Andersen, 2006). Wolverton (1979) used water hyacinth (vascular plants) to treat wastewater in lagoons. Gersberg et al. (1984) used Cattial (Typhaceae) and Bulrush (Scirpus) to remove sewage water nitrogen in an artificial wetland. The results of this study showed $97 \%$ and $94 \%$ removal efficiency of total mineral nitrogen and total nitrogen, respectively, by the plants. The nitrogen uptake by the plants was used to control wastewater Biological Oxygen Demand (BOD) and Total Suspended Solids (TSS) in artificial wetlands.

Plant extraction is a method which has been applied to minimize the effects of human activities on the environment that generate high amounts of residues. Plants on the soil surface can reduce soil erosion and runoff, and effect the transfer of pollutants to other areas (Quinton and Catt, 2007). Öztürk et al. (2015) highlighted that the total amount of pollutants was reduced by 
frequent cultivation in the Abadan refinery in Iran. Evapotranspiration of plants is also a permanent method for phytoremediation in some specific regions (Lombi et al., 2001).

The Sungun copper mine complex, located in the Arasbaran area of the northwest of Iran, is registered as an ecological site by UNESCO. A copper processing factory there discharges contaminated wastewater. Not addressing the potential negative impacts of the mining activities can bring environmental problems with inevitable social and natural consequences (Jafarpour et al., 2017). Mitigation of the environmental impacts of the contaminated wastewater in this area requires a rapid, non-expensive and efficient solution. Jafarpour et al. (2017) were the first to investigate the accumulation of heavy metals in agricultural plants cultivated in wastewater from the copper mining factory of Sungun. The results show that some plants (wheat and beans) are most compatible with the environment and play a significant role in the absorption of the heavy metals and reduction of destructive effects caused by the pollutants contained in the wastewater.

The objective of this research was to investigate heavy metal absorbency by two native plants (Alhagi and Mallow) in the laboratory and the field environments. The progressive growth pattern of the two native plants and the absorbency of heavy metals in their aerial parts and the roots were studied in the laboratory. The field studies involved the measurement of the quantity of heavy metals absorbed by the two plants around the tailings dam and then zoning the pollution levels in the soil using geostatistical methods. The results of this research will shed some light on the difference between the quantity of heavy metal absorbency in the field and the laboratory, and to help manage the environment better on a global scale. Implementation of the findings of this research would contribute to a cleaner production of mining. 


\section{Materials and methods}

\subsection{Study area}

The Sungun copper complex situated in the East Azerbaijan province is $130 \mathrm{~km}$ away from the city of Tabriz in the northwest of Iran (Fig. 1A). This mining complex is the largest open-cast mine in Iran and among leading global copper belts. It is placed on a geological intrusion on the Arasbaran mountain area (Qaradag) and the mine can be considered as a porphyry type. The main biomineralization of the mine contains copper and molybdenum and is recognized as the secondlargest producer of copper in Iran (Aghajani Bazzazi et al., 2011). The extractable reserves of this mine are approximately $995 \mathrm{Mt}$ and the copper grade is $0.61 \%$ (Jafarpour et al., 2017).

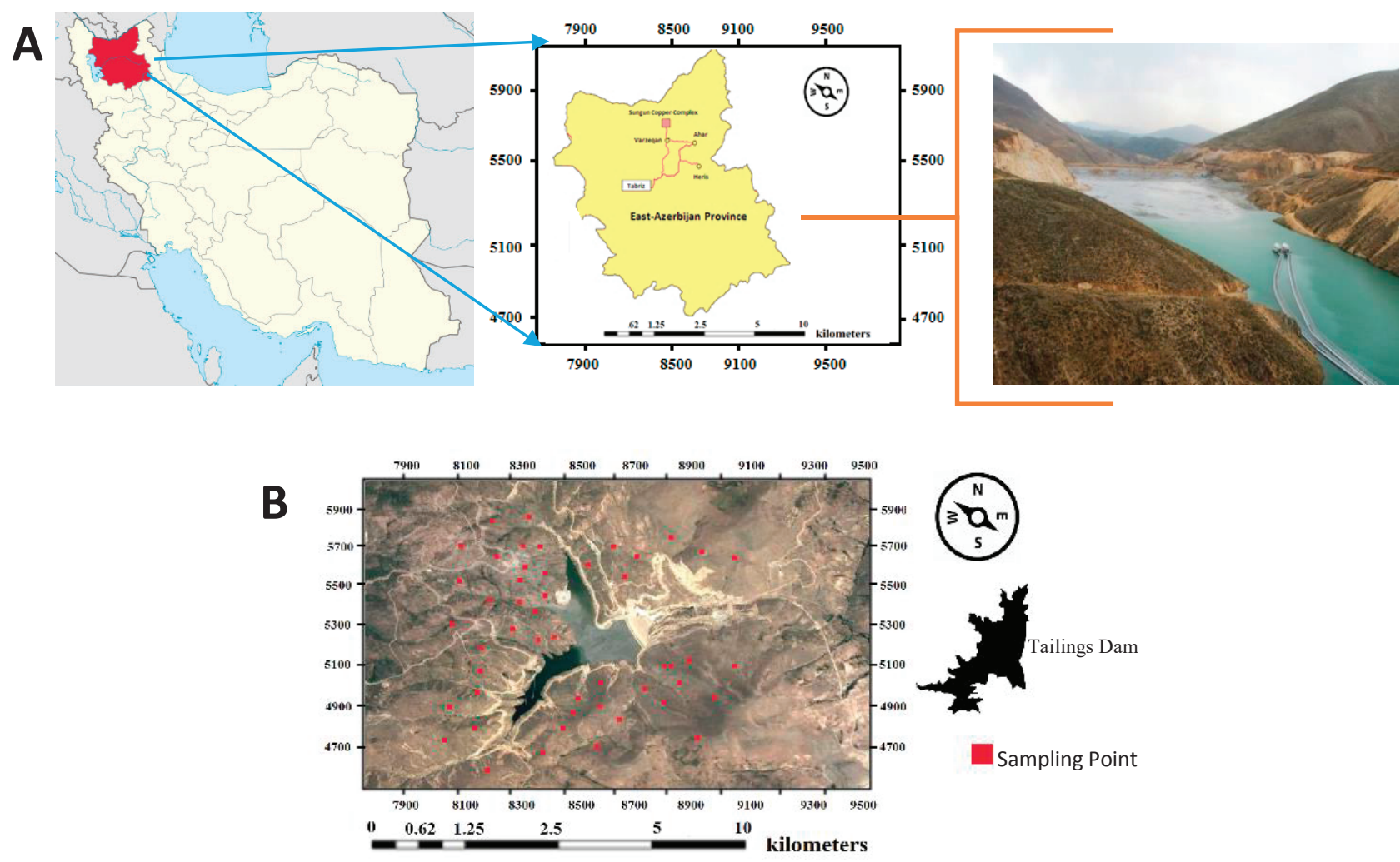

Fig. 1. Location of the Sungun copper complex; A) Study area, and B) Sampling sites. 
The processes of exploitation and production in the mine are displayed in Fig. 2. The extracted mineral is sent to a concentration factory and the solid waste materials are piled up at the waste dump. After crushing, milling and flotation processes, the product is sent to the market as a low-grade metal. The wastewater resulting from the processing is accumulated in the tailings dam near the mine (Fig. 1B). There are several potential hotspots of pollution during the production chain.

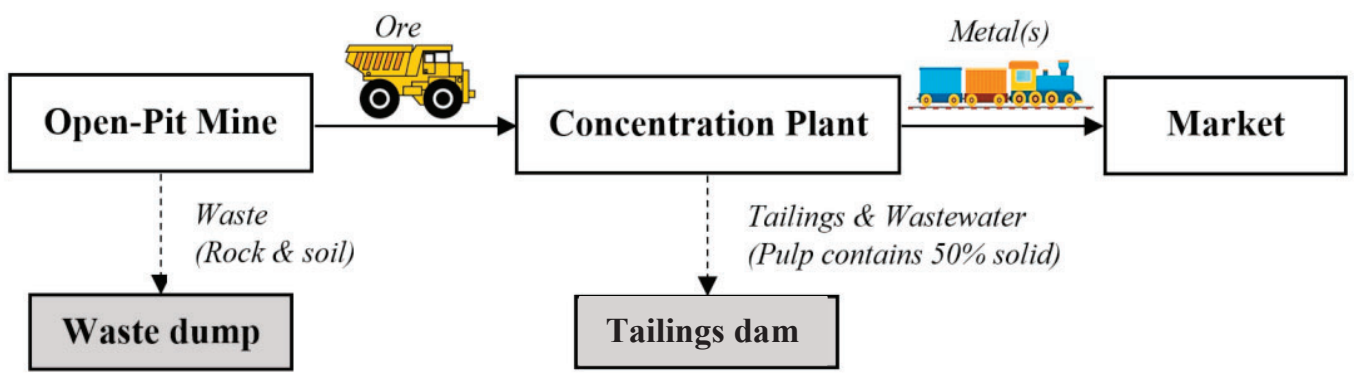

Fig. 2. A scheme of wastewater production processes in mining industries.

\subsection{Methodology}

This research was conducted following four major steps:

- plant selection and cultivation;

- plant heavy metal absorption analysis;

- $\quad$ soil sampling and chemical composition analysis; and

- soil mapping and geostatistical methods. 


\subsubsection{Plant selection and cultivation}

The Alhagi and the Mallow plant species which are in abundance in the region were selected for this study. The Alhagi plant is a durable plant belonging to the Papilionaceae Fabaceae family and sub-category of Faboideae. The fruit of this plant family is indehiscent. Its bushes are half-shrub and half-wood, reaching between 50 to $150 \mathrm{~cm}$ high. The plant stems are green with sharp yellow thorns. There is no indumentum on its sepals and the shape is bell-like with 5 sharp triangular dents. The seeds are placed beside each other in the pod (Jafarpour, 2016). The Mallow (Malva Sylveestris) is an herbaceous durable plant which reaches up to $60 \mathrm{~cm}$ high. It is a wild plant growing in many areas and is also cultivated. This plant is procumbent and it reaches up to $40 \mathrm{~cm}$ along the ground. The leaves are circular and pointed, and the flowers are violet and small (Jafarpour, 2016).

The two plants were cultivated in the laboratory for two months and irrigated using six different concentrations $(0 \%, 20 \%, 40 \%, 60 \%, 80 \%$, and $100 \%)$ of pulp (industrial wastewater

from the copper mine having different compositions of heavy metals) in normal water. These concentrations are considered as the treatments in the statistical analysis. Plant properties of root length, root weight, length of aerial parts, the weight of aerial parts, stem diameter, leaf area, and the number of bush leaves were measured at the end of the monitoring period. Five replications of the plants were cultivated for each treatment.

\subsubsection{Plant heavy metal absorption measurements}

The amounts of the accumulation of the heavy metals of chromium $(\mathrm{Cr})$, magnesium $(\mathrm{Mn})$, cadmium $(\mathrm{Cd})$, and lead $(\mathrm{Pb})$ in the plants were measured in the laboratory of Urmia University (West Azarbaijan province, Iran) using Atomic Absorption Spectroscopy PG990 equipment. The aerial parts and the roots were measured separately. 


\subsubsection{Soil sampling and chemical composition analysis}

A total of fifty sites were randomly selected around the tailings dam of the Sungun copper complex for soil sampling (Fig. 1B). Soil samples of $2 \mathrm{~kg}$ each were collected to a depth of $30 \mathrm{~cm}$ from the soil surface at each sampling site. The soil samples were dried and sieved, and particles finer than $2 \mathrm{~mm}$ were sent to the laboratory of Urmia University for heavy metal composition analysis. Established plants at some of the sampling sites were also taken to the laboratory for similar analysis to allow comparison of the heavy metals in the soil and the plants.

\subsubsection{Soil mapping and geostatistical methods}

Soil mapping was carried out through geostatistical methods using ArcGIS 10.2 (ESRI) and Google Earth images. Simple kriging and regression-kriging methods were employed. All data layers were converted into a regular grid (cellular) format. The experimental data (concentrations of heavy metals in the soil) were used for the regression-kriging along with a local variogram. A neuro-fuzzy relationship between superficial heavy element data and heavy element data was created, and the remainder was used to provide error mapping by a local variogram. To create a local variogram, the nearest grid to the predicted grid was chosen, and an experimental variogram was calculated based on the neighbouring grids. An appropriate model was fitted to the experimental variogram and the value of the heavy element was predicted (Shojaei, 2014; Franco et al., 2006).

One specific variogram calculated for the whole region was taken into consideration. A local variogram has been widely used in digital soil mapping (Gomez et al., 2012: Brus, 2019). The final soil map was acquired by a mixture of the neuro-fuzzy method (Quinlan, 2001) and the kriging error map (Shojaei, 2014). The preparation of the digital soil maps was based on the inverse distance weighting given as (Shojaei et al., 2017): 


$$
\hat{Z}_{j}=\frac{\sum_{i=1}^{N} \frac{Z_{i}}{h_{i j}^{\beta}}}{\sum_{i=1}^{N} \frac{1}{h_{i j}^{\beta}}}
$$

where $h_{i j}=\sqrt{d_{i j}^{2}+\sigma^{2}}$

\subsection{Statistical analysis}

Three standard performance statistics were used to assess the prediction capability of the geostatistical models (simple Kriging and regression-Kriging) developed. They are the root mean square error (RMSE), the correlation coefficient (R) and the mean absolute error (MAE) defined as (Seyedmohammadi et al., 2016):

$$
\begin{aligned}
& \text { RMSE }=\sqrt{\frac{1}{n} \sum_{i=1}^{n}\left(y_{i}-\hat{y}_{i}\right)^{2}} \\
& R=\sqrt{1-\left[\frac{\left(\sum_{i=1}^{n}\left(y_{i}-\hat{y}_{i}\right)^{2}\right)}{\left(\sum_{i=1}^{n}\left(y_{i}-\bar{y}_{i}\right)^{2}\right)}\right]} \\
& M A E=\frac{1}{n} \sum_{i=1}^{n}\left|y_{i}-\hat{y}_{i}\right|
\end{aligned}
$$

The physiological properties (root length, root weight, aerial parts length, aerial parts weight, stem diameter, leaf area, and bush leaves number) of the Alhagi and the Mallow plants which had been cultivated in the Sungun copper complex tailings dam with five replications were analyzed for the six treatments (i.e., the pulp concentrations) using SPSS version 16 (IBM, USA). 


\section{RESULTS AND DISCUSSION}

\subsection{Comparison of the means of the plant physiological properties of the Alhagi plant}

Comparing the average effect of the different pulp concentration treatments on the Alhagi plant, the highest root length occurred in the control (normal water) and an increase in the concentration of the pulp marginally decreased the root length. This is due to the availability of water and nutrients that retarded root growth, and there was no significant difference between the treatments (Fig. 3A). Other authors observed similar outcomes with soils affected by a high concentration of specific soil elements (Brillante et al., 2015; Pérez-de-los-Reyes et al., 2015). For the root weight features of the Alhagi plant, the control treatment had the highest value $(462.7 \mathrm{mg})$ and a pulp concentration of $20 \%$ decreased it to $390 \mathrm{mg}$. Further increase in the pulp concentration up to $60 \%$ caused a marginal decline in the root weight feature, but pulp concentration of $80 \%$ and higher significantly increased the root weight feature to $410 \mathrm{mg}$ (Fig. 3B). This observed trend corroborates Tai et al. (2018) and Demir and Sahin (2017) for different crops. The average weight of the Alhagi plant aerial parts showed a very different response to increase in the additive pulp concentration, as it increased from $465.5 \mathrm{mg}$ for the control to $468 \mathrm{mg}$ at $20 \%$ pulp concentrations. However, it decreased slightly between $40 \%$ and $60 \%$ pulp concentration and thereafter an increase of pulp concentration did not stimulate the plant area weight of the Alhagi plants (Nazir et al., 2019). We observed that there is no difference between these treatments at the $5 \%$ level of significance (Fig. 3C). Statistical significance test of a null hypothesis, in this case, that the treatments produce the same results, is associated with a p-value. The $5 \%$ significant level threshold is set such that if the p-value is less than 5\%, the null hypothesis cannot be rejected. In essence, the p-value is the probability of rejecting the null hypothesis should the experiment be 
repeated several times. Although the different concentrations of pulp have shown an increase in the weight of the aerial part, the contrary is the case for the root weight. A logical conclusion is that different concentrations of pulp are more effective in the aerial parts of the Alhagi plants than in their roots. These results corroborate the findings by Khan et al. (2019) on Nicotiana alata L. and Petunia hydrida L. using stabilizing heavy metals from wastewater.

The effect of the different treatments on the Alhagi plant stem diameter is depicted in Fig. $3 \mathrm{D}$. The results showed that the stem diameter in the control treatment was about $10 \%$ smaller than the pulp concentration treatments, which is very significant. Even though stem diameter growth has increased with the pulp concentration, the excessive use of pulp could cause a slight decline on the plant stem diameter, which is significant at the $5 \%$ level for pulp concentration above $80 \%$. As observed in Fig. 3D, the variation of the stem diameter rate is almost the opposite of the upper aerial parts which supports the findings of Martín et al. (2020) and Hejna et al. (2020) that plants with a heavier weight of aerial parts have a larger stem diameter.

As depicted in Fig. 3E, the pulp concentrations decreased the leaf area by about $4 \%$ compared with the control, although this decrease remained relatively constant irrespective of the pulp concentration. This could be due to the effect of pulp use after cultivating the plants in the soil (Mousa, 2009). Pulp causes a shock to the plant due to metal stress resulting from the difference in pulp concentration of the soil and water (Ashraf and Tang, 2017; Shojaei, 2016). The results also showed that this plant exhibits good resistance to metal stress and has been able to adapt to the conditions as demonstrated by Chen et al. (2017) and Tang et al. (2019).

Fig. 3F shows that the highest stem length growth occurred in the control treatments, while the pulp concentration treatments produced a constant reduction of about $6 \%$ due to stress caused 

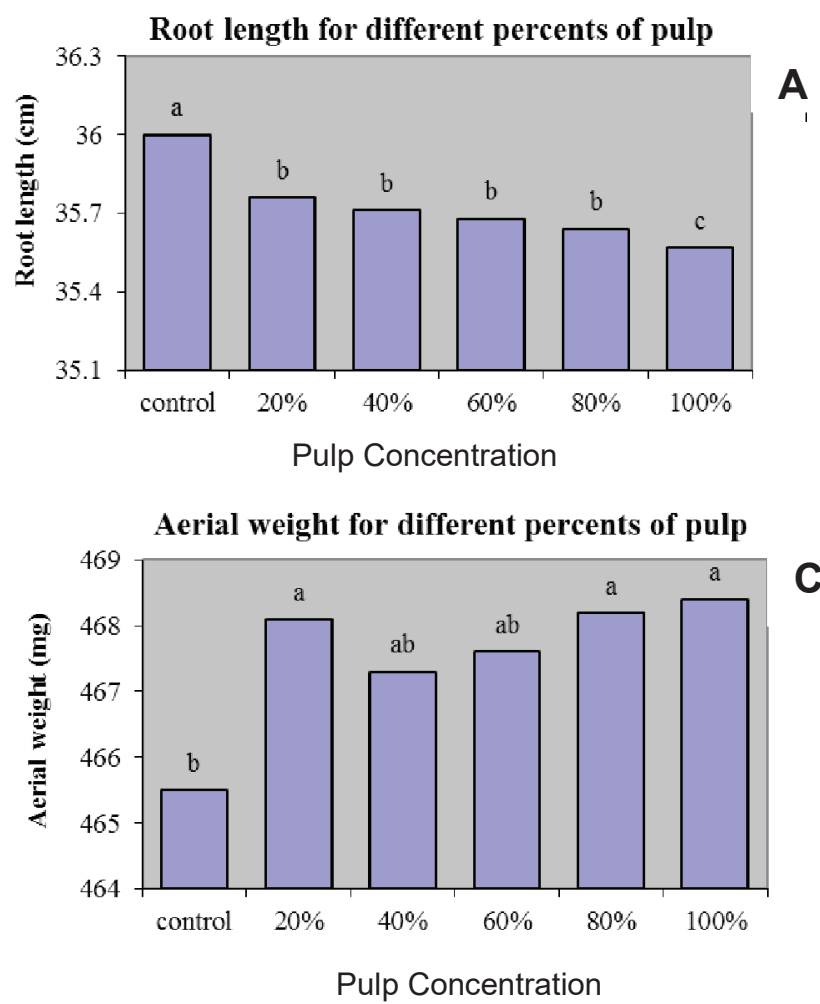
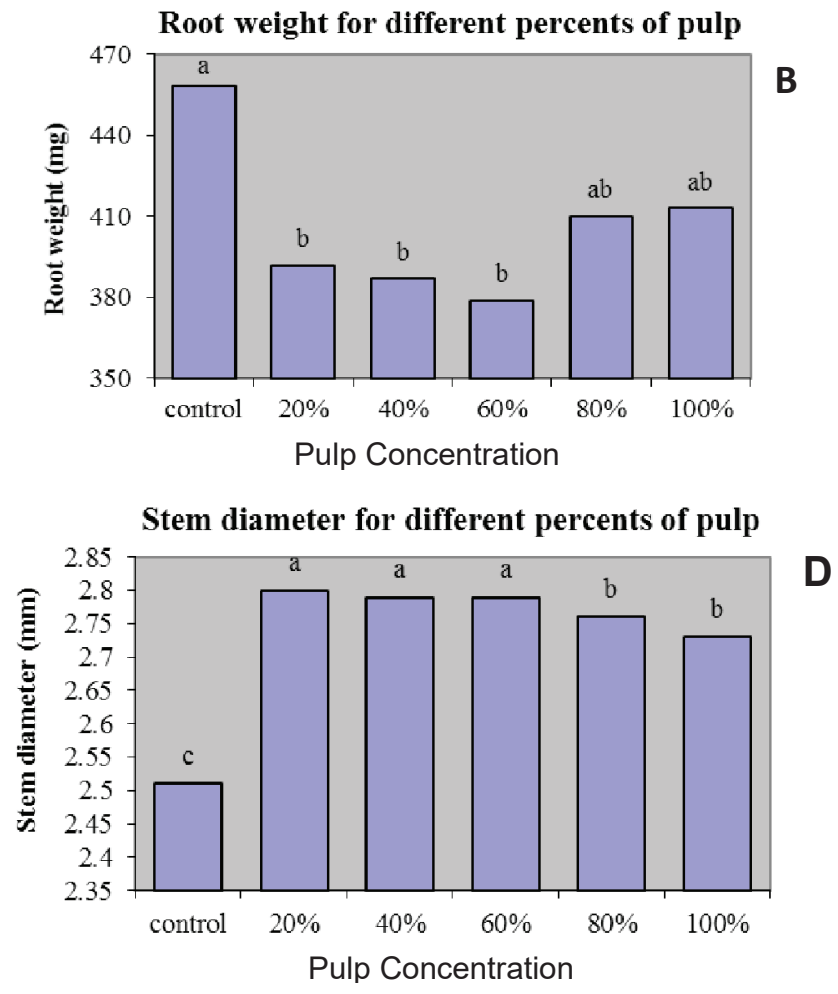
Leaf area for different percents of pulp

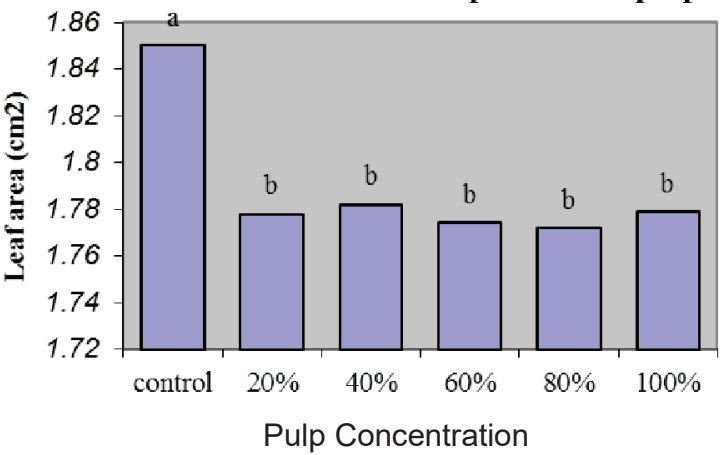

Leaf number for different percents of pulp

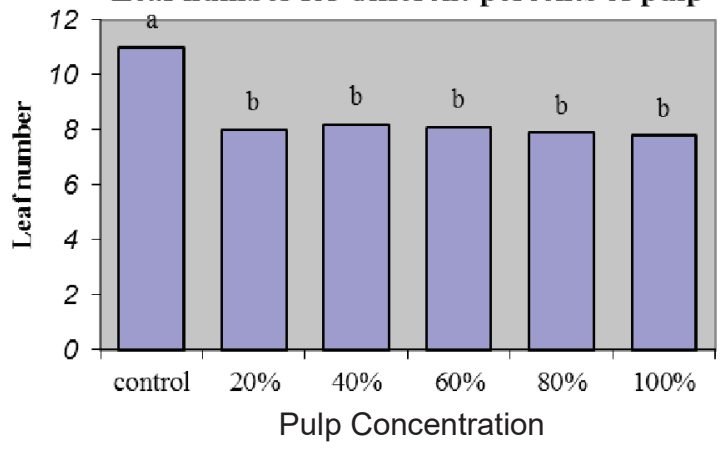

$E$

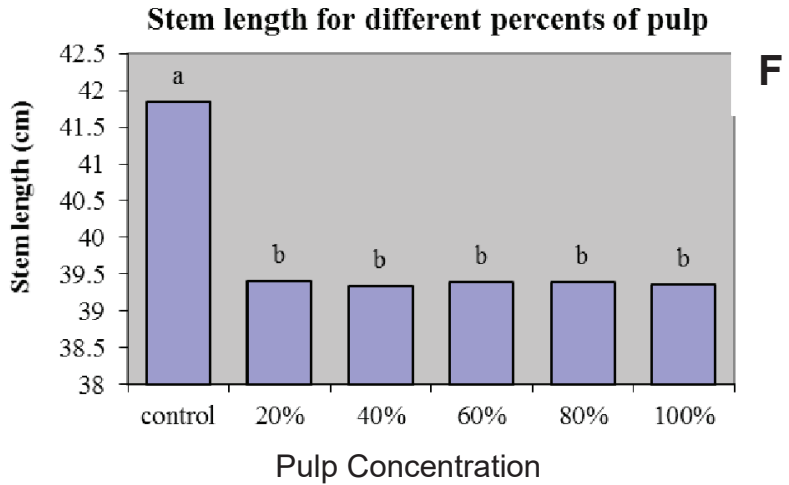

G Fig. 3. Comparison of the mean values of the physiological properties obtained for five Alhagi plants under different levels of pulp concentration; the mean values indicated with the same letters are not significantly different $(\mathrm{p}-$ value $<0.05, p$-value $=$ probability of rejecting the null hypothesis that they are the same should the experiment be repeated several times).

\subsection{Comparison of the physiological properties of the Mallow plant}

The average root length of the five Mallow plants for each of the pulp concentrations are shown in Fig. 4A. These results show that an increase in pulp concentration caused a decrease in the Mallow plant root length. There are significant differences between all the treatments at the $5 \%$ significance level, except for the $80 \%$ and $60 \%$ pulp treatments that are statistically similar. The results for the Mallow root weight also declined with the increase of pulp concentration (Fig 4B), noting that the concentrations of $20 \%$ and $40 \%$ are statistically similar but those above $40 \%$ are statistically different at the 5\% significance level. At the $20 \%$ pulp concentration level, the weight of the aerial part attained the highest value of $2250 \mathrm{mg}$, while there was no significant difference between the rest of the pulp concentration treatments up to $80 \%$. The lowest values 
occurred in the control and 100\% pulp concentration treatments (Fig. 4C). It appears that the sudden increase of the weight of aerial parts in cultivation with $20 \%$ pulp treatment was a reflection of the sudden increase in pulp concentration, and thereafter the Mallow maintained its previous natural condition (Saha et al., 2017).

With the increase of pulp concentration from $20 \%$ to $100 \%$, the Mallow stem diameter increased marginally without significant differences (Fig. 4D) which can be attributed to the amount of heavy metal accumulation in the plants (Jafarpour et al., 2017). It is noted that the largest Mallow stem diameter occurred in the control treatment (Fig. 4D). The variation of the stem diameter rate was in complete accordance with the weight of the aerial parts, which indicates the accuracy and precision of this experiment. The aerial part weight feature declined with an increase in stem diameter, and also its stem length decreased with increase in its aerial part weight as it adapts to metal stress (Jafarpour et al., 2017; Chen et al., 2017).

The largest leaf area of the Mallow plant of $8.12 \mathrm{~cm}$ was observed in the control treatment and it was significantly different from all pulp treatments at the 5\% significance level (Fig. 4E). The increase of pulp concentration affected the leaf area at a parabolic rate of shrinkage with the minimum occurring at $60 \%$ concentration, although the differences were not significant. Changes in the number of Mallow leaves is completely the reverse of the results for the leaf area. The Mallow leaf number increases with the pulp concentration at a parabolic rate with the maximum occurring at the $60 \%$ pulp concentration (Fig. 4G). These observed responses of the Mallow plant could be due to compensating physiological needs as it compensates the decline of leaf area with an increasing number of leaves (Sharma and Singh, 2019).

The results of the average Mallow plant stem length showed that increasing the pulp concentration of the Mallow plant irrigation water leads to an increase of the plant stem length, 
and there is a significant difference between the control and pulp irrigation treatments. The smallest stem lengths were observed in the control treatments, while the highest stem length occurred in the $20 \%$ pulp concentration. This is because this amount of pulp percentage had satisfied the plant's nutrients needs and had led to its growth, but the additional increase of pulp concentration caused a decline in its growth which may have been due to the stress resulting from heavy metals accumulation in the plant's organs (Fig. 4F) as has been reported by Kehrein et al. (2020).

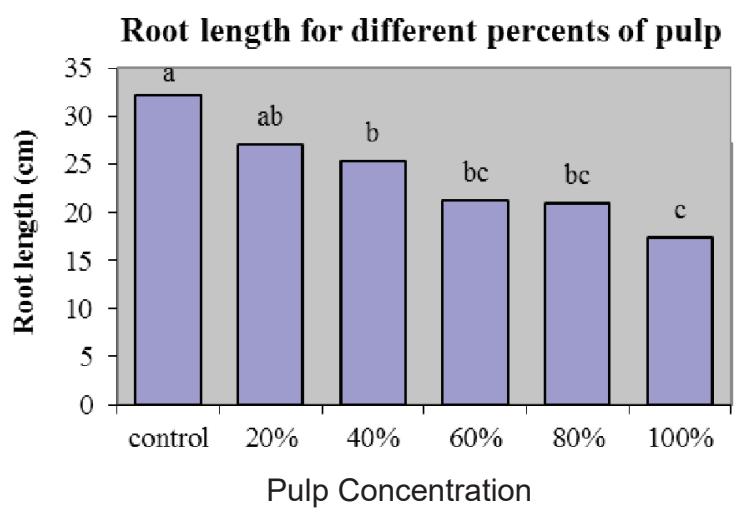

A

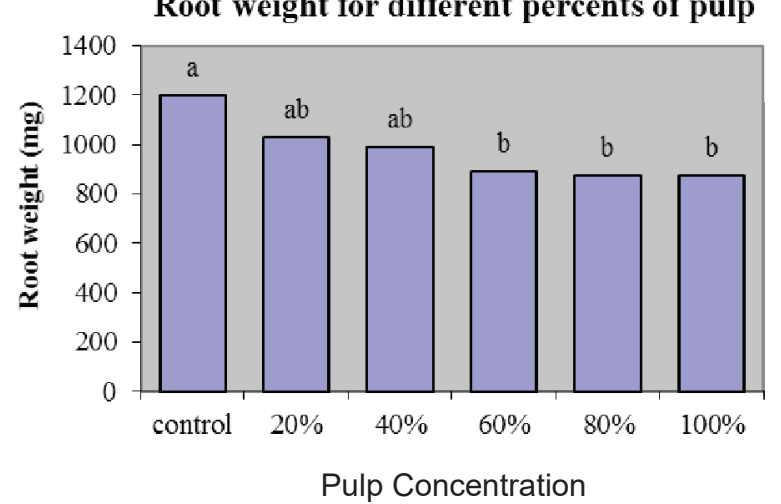

B
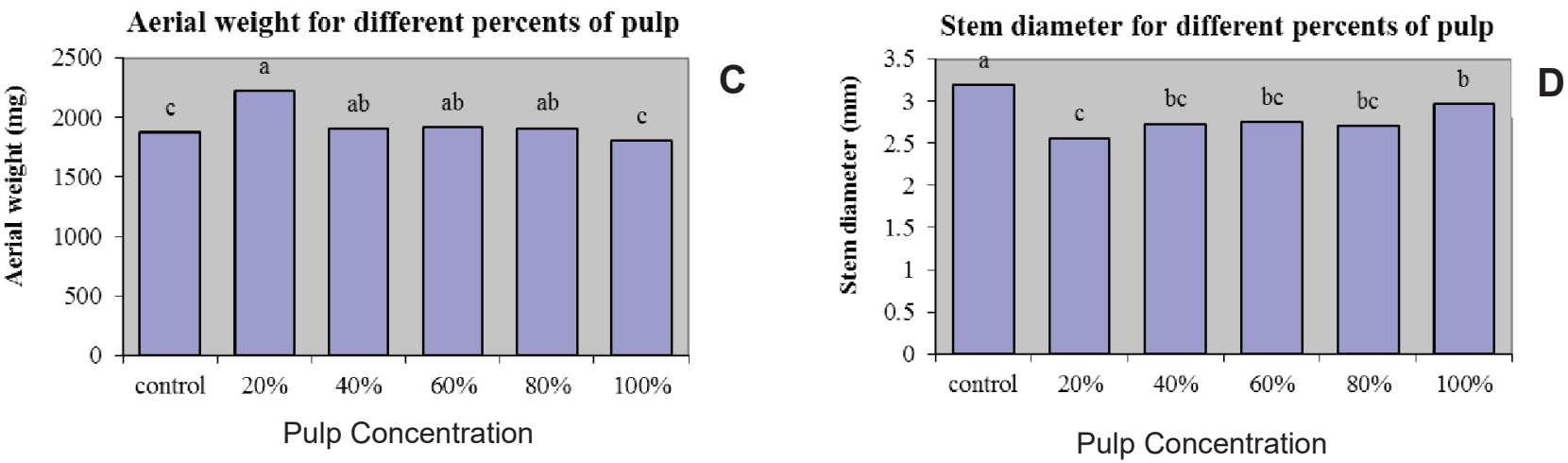


\subsection{Analysis of metal accumulation in plants}

The absorption of heavy metals $(\mathrm{Cr}, \mathrm{Mn}, \mathrm{Cd}$, and $\mathrm{Pb})$ in the aerial parts and the roots of the plants were analyzed using the PG-990 equipment. The results of the chemical analysis of the Alhagi and the Mallow plants are presented in Figs. 5 to 8. Fig. 5 indicates that the amount of $\mathrm{Cr}$ in the roots of the plants is far more than found in their aerial parts (stem and leaf) for all treatments. It is worth indicating that the amount of $\mathrm{Cr}$ absorption by the Alhagi plant is much more than that of the Mallow plant. Similarly, the amount of $\mathrm{Mn}$ in the roots of the plants is far more than that 
absorbed in their aerial parts for all treatments, and the two plants show similar accumulation values (Fig. 6). As observed for $\mathrm{Cr}$ and $\mathrm{Mn}$, the accumulation of $\mathrm{Cd}$ and $\mathrm{Pb}$ in the roots of the plants are also far greater than stored in the aerial parts for all different treatments (Fig. 7 and 8). However, $\mathrm{Cd}$ accumulation reached a peak at the $60 \%$ pulp concentration and declined with further increase in the pulp concentration. The $\mathrm{Pb}$ accumulation showed a similar pattern but with the peak values occurring at $80 \%$ pulp concentration.

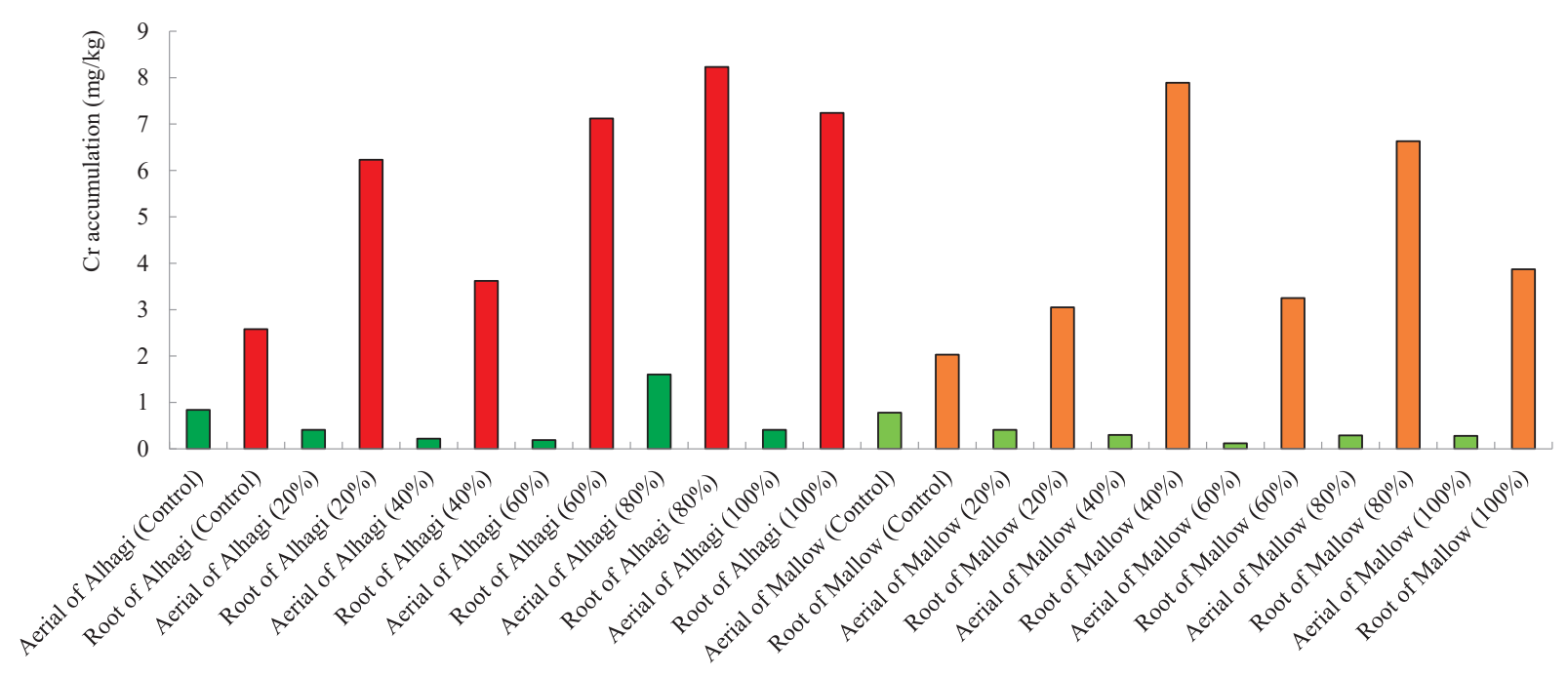

Fig 5. Accumulation of chromium $(\mathrm{Cr})$ in the aerial parts and roots of the Alhagi and the Mallow plants for the different treatments. 
Fig 7. Accumulation of cadmium $(\mathrm{Cd})$ in the aerial parts and roots of the Alhagi and the Mallow plants for the different treatments.

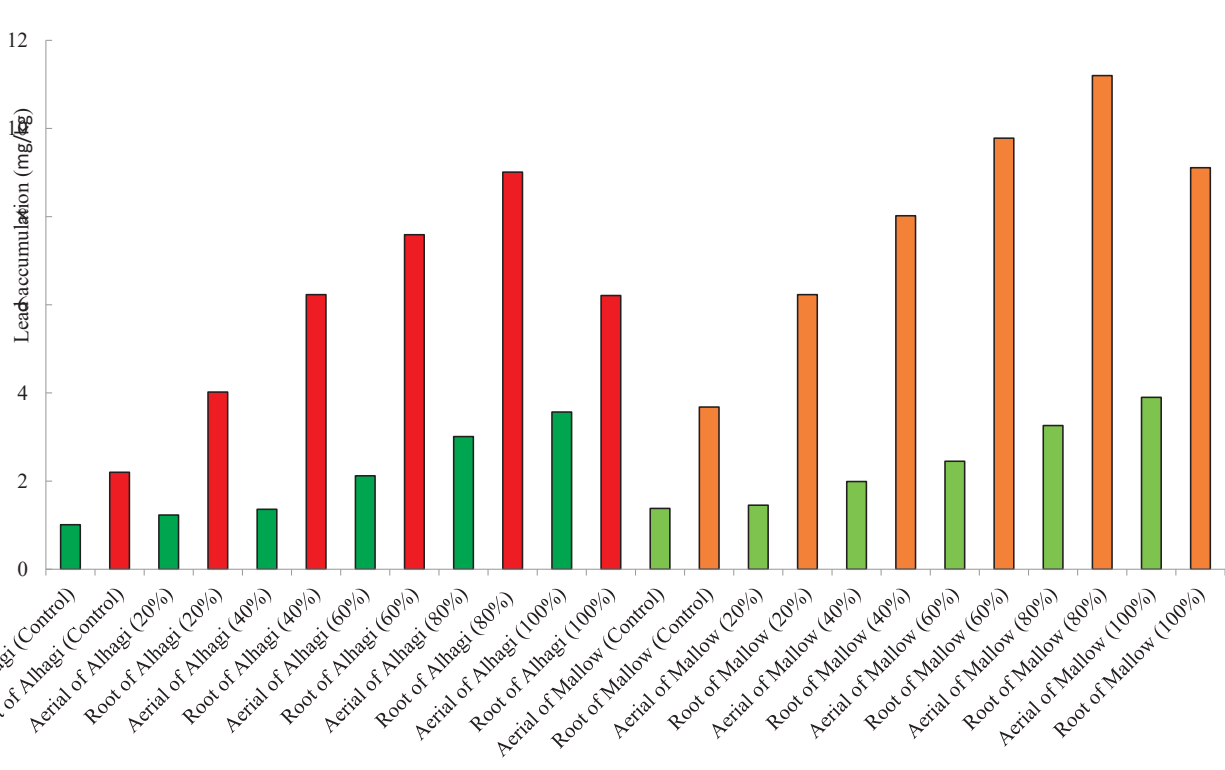

Fig 8. Accumulation of lead in the aerial parts and roots of the Alhagi and the Mallow plants for the different treatments.
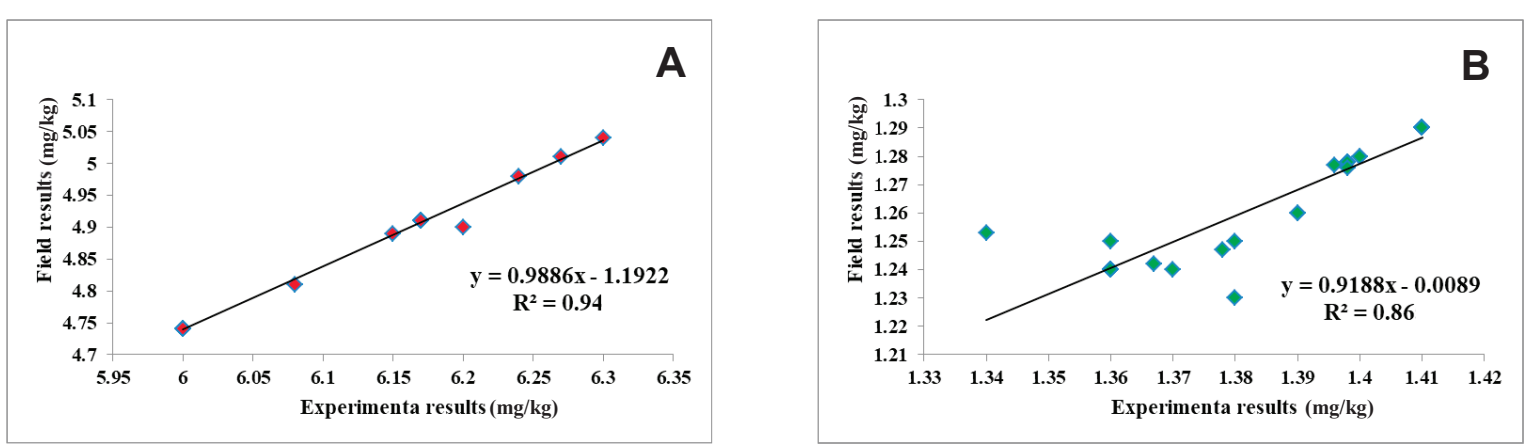

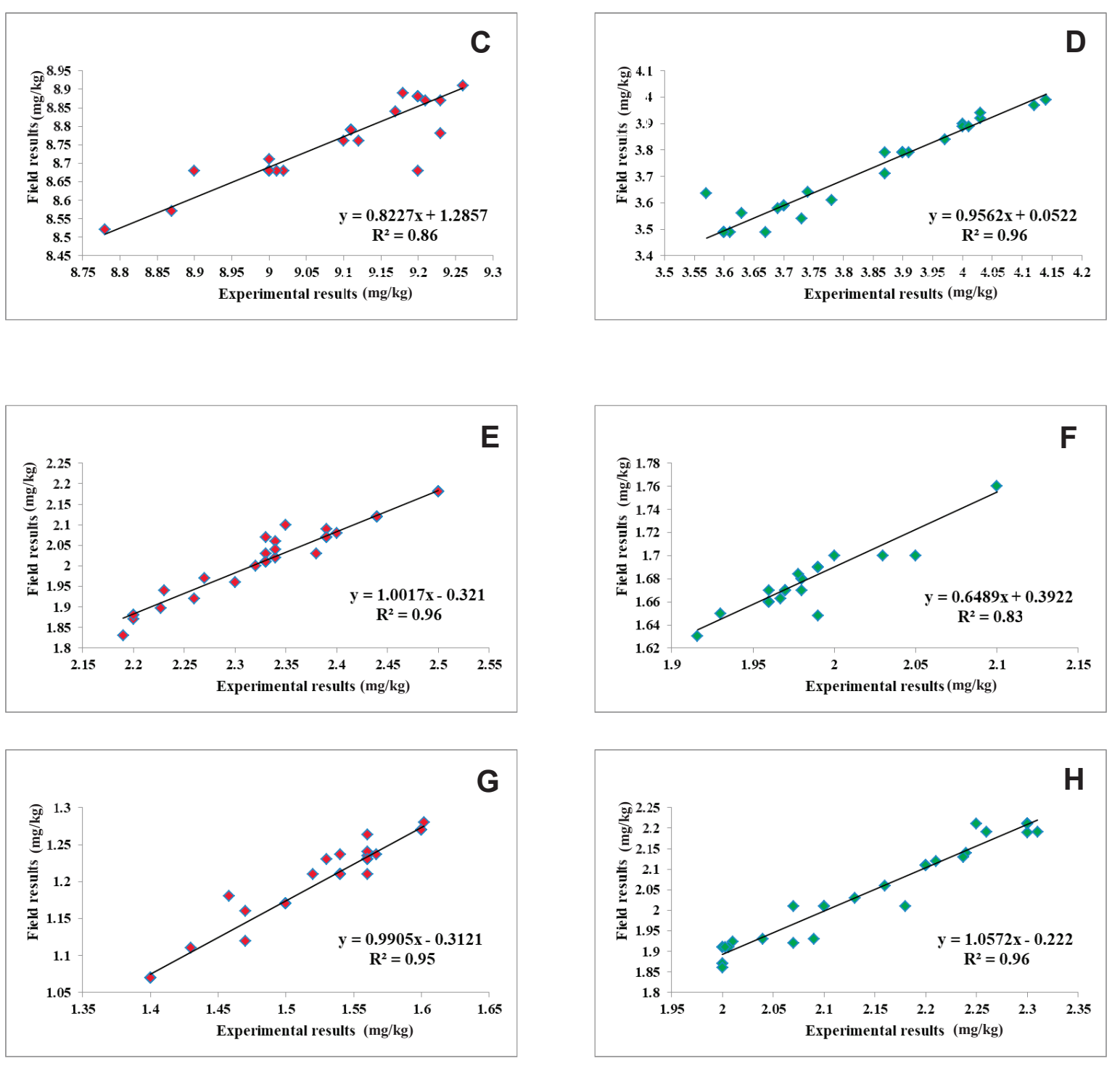

Fig. 9 (part 1) Comparison of heavy metal absorption by the plants in the laboratory and around the tailings dam (Field). 

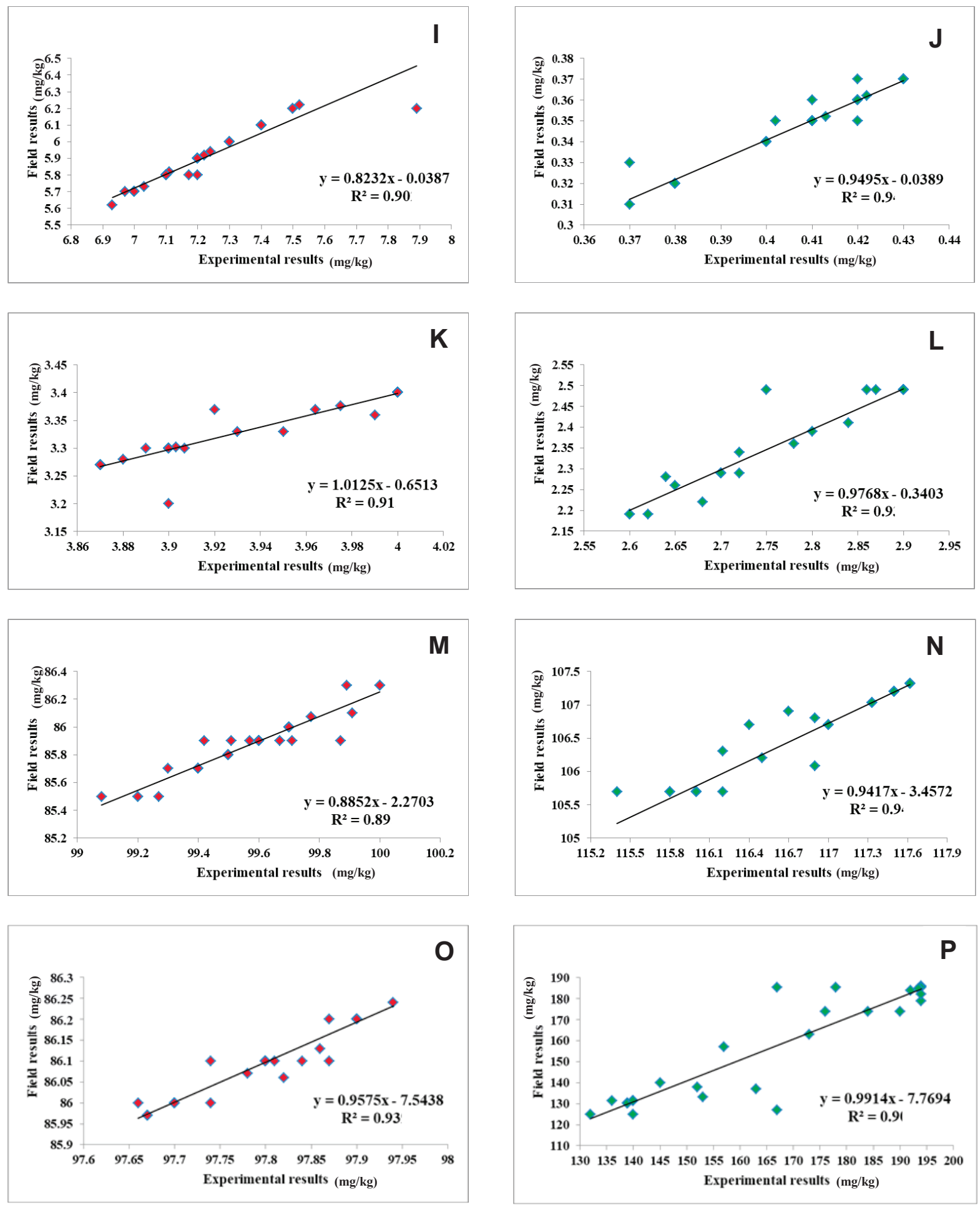

Fig. 9 (part 2) Comparison of heavy metal absorption by the plants in the laboratory and around the tailings dam (Field). 
A regression analysis was conducted between the concentrations of heavy metals in the soil samples taken from the tailings dam and those accumulated in the roots and aerial parts of the plants growing at the same location. The results showed that there is a positive linear relationship $\left(\mathrm{R}^{2}>0.83\right)$ between the concentration of the heavy metals in the soil and their accumulation in the plants (Fig. 9F). Fig. 9 indicates that there was a high correlation between the soil and plant values for $\mathrm{Pb}\left(R^{2}=0.94\right)$ and $\mathrm{Cd}\left(R^{2}=0.97\right)$ in the Alhagi plant root compared to the Mallow plant (Fig. 9A and 9E), and the root of the Alhagi plant displayed a higher absorption level of $\mathrm{Pb}$ and $\mathrm{Cd}$ in its aerial parts (Fig. 9B and 9F). There was a high correlation for the $\operatorname{Cr}\left(R^{2}=0.91\right)$ and $\operatorname{Mn}\left(R^{2}=\right.$ 0.94) in the Mallow root compared to the Alhagi, and the root of the Mallow has higher absorption of $\mathrm{Cr}$ and $\mathrm{Mn}$ (Fig. 9K and 9O). The maximum accumulation of heavy elements was seen in $\mathrm{Cr}$ and $\mathrm{Mn}$ in the Alhagi aerial parts (Fig. 9J and 9N). The results showed that the concentration of the heavy metals in parts of the plants depends on the soil and absorption by the plant (Singh et al., 2004; Gascó and Lobo, 2007; Sharma et al., 2007; Beigi Harchegani and Banitalebi, 2013). It is observed that the accumulation of heavy elements in different parts (root or aerial parts) varies significantly in the herbaceous Mallow plant. The results obtained from the soil and plants in the region indicated that there was a high correlation in terms of accumulation of $\mathrm{Pb}$ and $\mathrm{Cd}$ in the root of the Alhagi plant compared to that of the Mallow plant. On the contrary, the highest accumulation of $\mathrm{Pb}$ and $\mathrm{Cd}$ in the Mallow plant was found in the aerial parts. Regarding $\mathrm{Mn}$ and $\mathrm{Cr}$, the correlation of heavy element absorption from soil to plant in the roots of the Mallow plant was more than in the Alhagi plant. By comparing the values between the field and the experimental results, it was concluded that the change in the value and the process of heavy metal absorption is different. In the natural environment, due to some conditions such as rainfall, temperature, 
evaporation, guttation, and physical and chemical properties of the soil, the results could be relatively different from the experimental values (Kumar et al., 2019; Radziemska et al., 2019).

\subsection{Spatial Mapping}

The concentration of the heavy metals in parts of the plants depends on the soil's heavy metal concentration levels and absorption by the plant, which is based on Beigi's theory (Singh et al., 2004; Gascó and Lobo, 2007; Sharma et al., 2007; Beigi Harchegani and Banitalebi, 2013). Table 1 shows the basic statistics of the concentrations of heavy metals data for the collected soil samples. Based on the obtained results, the average values of $\mathrm{Cr}, \mathrm{Mn}, \mathrm{Cd}$, and $\mathrm{Pb}$ in the top layer of $0-30 \mathrm{~cm}$ of the soil were $25.2,368.6,9.5$, and $36.9 \mathrm{mg}$, respectively. The summary of the application of the regression-kriging method for the heavy elements is presented in Table 2 . The regression-kriging method in ArcGIS setting was used to model the spatial changes of heavy metal absorption in the region. It obtained a better result than the simple kriging method based on the performance statistics of MAE, R and RMSE. A similar finding was obtained by Mehrjardi et al. (2008) and Wang et al. (2013) comparing kriging, inverse-distance-weighted and co-kriging interpolation methods for predicting the spatial distribution of soils. $\mathrm{Pb}$ and $\mathrm{Cd}$ had the best precision of estimation because they yielded the minimum RMSE. Zehtabian et al. (2013) used geostatistical methods for soil quality observations in the Dameghan in the Semnan Province of Iran. Their comparison of various geostatistical methods showed that the kriging technique outperformed the other techniques for characterization of the spatial variability of soil properties.

Fig. 10 depicts the modelled spatial distribution of the heavy metals around the tailings dam. The results showed that $\mathrm{Pb}$ and $\mathrm{Cd}$ exhibit high concentrations around the tailings dam and the concentration decreases as you move away from the tailings dam. However, $\mathrm{Cr}$ is highly 
concentrated in the south-west corner and $\mathrm{Mn}$ is concentrated more in the southern part of the tailings dam.

One of the most important consequences of mining is environmental pollution including high volumes of heavy metal concentrations in wastewater. The direct discharge of wastewater into the surrounding areas of open-cast mines results in irreparable damage to the environment (Kumar et al., 2019; Mariet et al., 2017; Rodríguez-Seijo et al., 2014). Environmental compliance of mining operations is, therefore, paramount.

Table1. Summary of heavy metals in the fifty soils samples $(0-30 \mathrm{~cm})$ in $\mathrm{mg} / \mathrm{kg}$.

\begin{tabular}{lccc}
\hline Element & Minimum & Maximum & Average \\
\hline $\mathrm{Cr}$ & 36.1 & 1.5 & 25.2 \\
$\mathrm{Mn}$ & 558 & 292.3 & 368.6 \\
$\mathrm{Cd}$ & 12.5 & 8.3 & 9.5 \\
$\mathrm{~Pb}$ & 42.8 & 14.7 & 36.9 \\
\hline
\end{tabular}

Table 2. Performance statistics for the evaluation of the models.

\begin{tabular}{lccc}
\hline Variable & R (-) & RMSE $(\mathrm{mg} / \mathrm{kg})$ & MAE $(\mathrm{mg} / \mathrm{kg})$ \\
\hline & & Regression - Kriging & \\
$\mathrm{Pb}$ & 0.091 & 0.090 & 0.94 \\
$\mathrm{Cd}$ & 0.93 & 0.100 & 0.90 \\
$\mathrm{Mn}$ & 0.95 & 0.103 & 0.88
\end{tabular}



$\mathrm{Cr}$
0.96
0.111
0.87

\section{Kriging Simple}

$\begin{array}{cccc}\mathrm{Pb} & 0.89 & 0.190 & 0.96 \\ \mathrm{Cd} & 0.90 & 0.230 & 0.93 \\ \mathrm{Mn} & 0.90 & 0.107 & 0.88 \\ \mathrm{Cr} & 0.91 & 0.207 & 0.90\end{array}$

RMSE - Root-mean-square error; MAE - Mean absolute error 


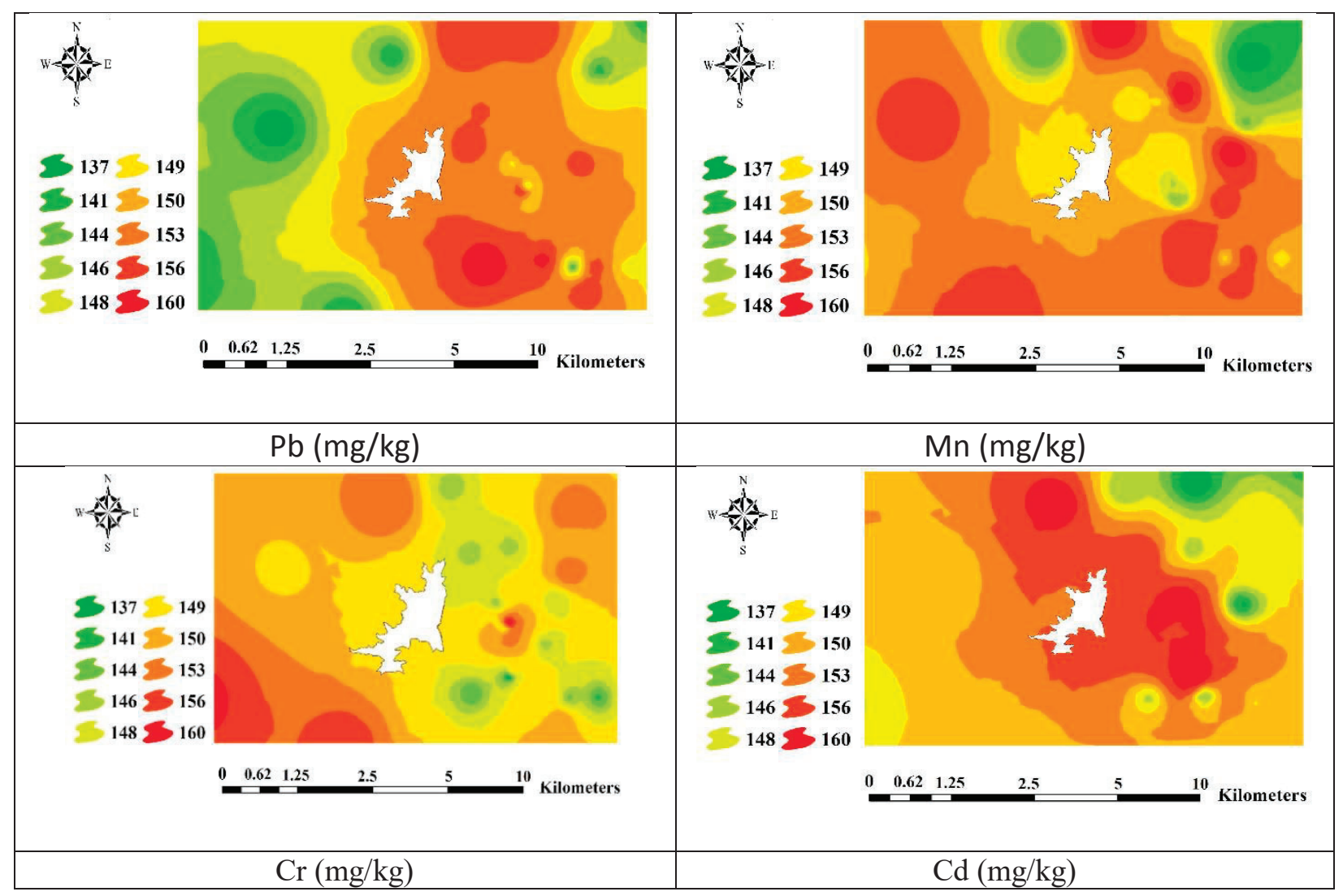

Fig. 10. Spatial distribution map of the heavy metals by the regression-kriging method.

\section{Conclusion}

The paper studied the absorption of heavy elements ( $\mathrm{Pb}, \mathrm{Mn}, \mathrm{Cr}$ and $\mathrm{Cd})$ by two native plants (Alhagi and Mallow) in the laboratory and under natural conditions around a tailings dam in Iran. In the laboratory the two species of plants were cultivated and irrigated with water having different pulp concentrations, $0 \%$ being the natural (normal) water as the control. Heavy metal absorption by the plants in the aerial parts and the roots were monitored at the end of two months. 
Plant physiological parameters of the root length, root weight, leaf surface, and leaf numbers were measured and evaluated against the pulp concentrations considered as treatments. Generally, the physiological parameters of root length, root weight, and leaf area declined with increasing pulp concentration with the statistical difference among the treatments being more pronounced with the Alhagi plant. The length of the aerial parts and stem diameter showed a general tendency of increasing with increasing pulp concentration. For the Mallow plant, the root length, root weight, stem diameter, and leaf area decreased with increase in wastewater concentration, the weight of aerial parts had an increasing trend compared to the control treatment. The reason could be related to an increase in the concentration of heavy elements in these two plants which causes a shock in the plants and different responses were seen in the aerial parts and roots. The heavy metal accumulation in the plants under laboratory conditions indicated that the concentrations of $\mathrm{Pb}, \mathrm{Mn}$, $\mathrm{Cr}$, and $\mathrm{Cd}$ in the roots were far more than in the aerial parts. There was a positive and significant correlation between the concentration of heavy elements in the soil and the aerial parts and roots of the Alhagi and Mallow plants growing on the soil. As there was a considerable amount of $\mathrm{Pb}$ and $\mathrm{Cd}$ in the tailings dam, their concentrations in both soils and plants around the tailings dam were higher and compatible with the mapping. It is recommended to encourage plant harvesting to help reduce the migration of the heavy metals from the contaminated soils into the surrounding environment. The type of vegetation chosen must be guided by the type of pollution ( $\mathrm{Pb}, \mathrm{Mn}, \mathrm{Cr}$, $\mathrm{Cd}$, etc.) produced by the industry, as for the studied area the Alhagi plant is better suited for absorbing $\mathrm{Cr}$ and $\mathrm{Cd}$. As the maximum molar of heavy elements absorbed by a plant varies in different organs of the plant (aerial or underground organs), attention should be paid to this subject in the use of the harvested plants method to get the cleanest production. 
Much research effort has been devoted to describing the threat of environmental pollution which is regarded as a global problem. It is suggested a shift is required to understanding the advantages of plant extraction, as well as the potential strategy to promote regular harvesting. As established, the lack of industry willingness to use harvested plants is the biggest obstacle for the research of plant extraction. Therefore, plant extraction must be a priority topic for future research, to improve upon the achievement of cleaner industrial production.

\section{Declaration of Competing Interest}

The authors declare that they have no known competing financial interests or personal relationships that could have appeared to influence the work reported in this paper.

\section{Acknowledgements}

Authors are grateful to the Yazd University for their continuing financial support for this research.

Appendix Table 1: Nomenclature.

\begin{tabular}{|l|l|}
\hline BOD & Biological oxygen demand \\
\hline TSS & Total suspended solids \\
\hline UNESCO & $\begin{array}{l}\text { United Nations Educational, Scientific and } \\
\text { Cultural Organization }\end{array}$ \\
\hline Alhagi & Alhagi persarum \\
\hline
\end{tabular}




\begin{tabular}{|c|c|}
\hline Mallow & Malva Sylveestris \\
\hline $\mathrm{Cr}$ & Chromium \\
\hline $\mathrm{Mn}$ & Magnesium \\
\hline $\mathrm{Cd}$ & Cadmium \\
\hline $\mathrm{Pb}$ & Lead \\
\hline GIS & Geographic information system \\
\hline RMSE & Root mean square error \\
\hline MAE & Mean absolute error \\
\hline $\mathrm{R}$ & Correlation coefficient \\
\hline$y_{i}$ & Denotes the measured value \\
\hline$\hat{y}_{i}$ & Predicted value \\
\hline $\bar{y}_{i}$ & Average of the measured values \\
\hline$n$ & Total number of observations \\
\hline$h_{i j}$ & $\begin{array}{l}\text { Effective distance between the network grid (j) } \\
\text { and neighbouring grid (i) }\end{array}$ \\
\hline$\hat{Z}_{j}$ & Estimated value of parameter $Z$ \\
\hline$Z_{i}$ & $\begin{array}{l}\text { True value of parameter } \mathrm{Z} \text { in the neighbouring } \\
\text { grid }\end{array}$ \\
\hline$d_{i j}$ & $\begin{array}{l}\text { Distance between the network grid (j) and } \\
\text { neighbouring grid (i) }\end{array}$ \\
\hline$\beta$ & Weighted power which was set to 3 \\
\hline$\sigma$ & smoothing coefficient \\
\hline
\end{tabular}




\section{References}

Acín-Carrera, M., José Marques, M., Carral, P., Álvarez, A.M., López, C., Martín-López, B., González, J.A., 2013. Impacts of land-use intensity on soil organic carbon content, soil structure and water-holding capacity. Soil Use Manage. 29(4), 547-556. https://doi.org/10.1111/sum.12064

Ashraf, U., and Tang, X., 2017. Yield and quality responses, plant metabolism and metal distribution pattern in aromatic rice under lead $(\mathrm{Pb})$ toxicity. Chemosphere, 176, 141-155.

Aghajani Bazzazi, A., Osanloo, M., and Karimi, B., 2011. A new fuzzy multi criteria decision making model for open pit mines equipment selection. APJOR, 28(03), 279-300.

Andersen, R. G., 2006. In situ characterization and quantification of phytoremediation removal mechanisms for naphthalene at a creosote-contaminated site (Doctoral dissertation, Virginia Tech). https://vtechworks.lib.vt.edu/handle/10919/26408

Brillante, L., Mathieu, O., Bois, B., van Leeuwen, C., Lévêque, J., 2015. The use of soil electrical resistivity to monitor plant and soil water relationships in vineyards. Soil, 1(1), 273-286. https://doi.org/10.5194/soil-1-2732015

Bandala, E.R., Rodriguez-Narvaez, O.M., 2019. On the Nature of Hydrodynamic Cavitation Process and Its Application for the Removal of Water Pollutants. Air, Soil Water Res. 12, 1178622119880488. https://doi.org/10.1177/1178622119880488

Brus, D. J., 2019. Sampling for digital soil mapping: A tutorial supported by R scripts. Geoderma, 338, 464-480.

Beigi, H. H., and Banitalebi, G., 2013. The effect of twenty-three years of surface irrigation with treated municipality wastewater on soil loadings, transfer to wheat and corn grains, and related health risks of some heavy metals. JWSS.27 (2): 570-580.

Bagherifard, A., Hamidoghli, Y., Biglouei, M. H., Ghaedi, M., 2020. Effects of drought stress and superabsorbent polymer on morpho-physiological and biochemical traits of Caper ('Capparis spinosa L.). Aust. J. Crop Sci. 14(1), $13-20$.

Chen, C., Xin, K., Liu, H., Cheng, J., Shen, X., Wang, Y., Zhang, L., 2017. Pantoea alhagi, a novel endophytic bacterium with ability to improve growth and drought tolerance in wheat. Sci. Rep, 7(1), 1-14.

Dierberg, F. E., and DeBusk, T. A., 2008. Particulate phosphorus transformations in south Florida stormwater treatment areas used for Everglades protection. Ecol. Eng. 34(2), 100-115. 
Demir, A. D., and Sahin, U., 2017. Effects of different irrigation practices using treated wastewater on tomato yields, quality, water productivity, and soil and fruit mineral contents. Environ. Sci. Pollut. Res. 24(32), 24856-24879.

Franco, C., Soares, A., and Delgado, J., 2006. Geostatistical modelling of heavy metal contamination in the topsoil of Guadiamar River margins (S Spain) using a stochastic simulation technique. Geoderma, 136(3-4), 852-864.

Lombi, E., Zhao, F. J., Dunham, S. J., McGrath, S. P., 2001. Phytoremediation of heavy metal-contaminated soils: Natural hyperaccumulation versus chemically enhanced phytoextraction. J. Environ. Qual. 30(6), 1919-1926.

Gascó, G., Lobo, M.C., 2007. Composition of Spanish sewage sludge and effects on treated soil and olive trees. Waste Manage. (Oxford, U. K.), 27 (11): 1494-1500.

Gerhardt, K. E., Huang, X. D., Glick, B. R., Greenberg, B. M., 2009. Phytoremediation and rhizoremediation of organic soil contaminants: potential and challenges. Plant Sci., 176(1), 20-30.

Gersberg, R. M., Elkins, B. V., Goldman, C. R., 1984. Use of artificial wetlands to remove nitrogen from wastewater. J. Water Pollut. Control Fed., 56, 152-156.

Gomez, C., Lagacherie, P., Coulouma, G., 2012. Regional predictions of eight common soil properties and their spatial structures from hyperspectral Vis-NIR data. Geoderma, 189, 176-185.

Hietala-Koivu, R., Lankosko, J., Tarmi, S., 2004. Loss of biodiversity and its social cost in an agricultural landscape. Agriculture Ecosystems \& Environment 103, 75-83.

Howe, J., Wagner, M., 1999. Effects of pulp mill effluent irrigation on the distribution of elements in the profile of an arid region soil. Environ. Pollut., 105: 129-135.

Hejna, M., Moscatelli, A., Stroppa, N., Onelli, E., Pilu, S., Baldi, A., Rossi, L., 2020. Bioaccumulation of heavy metals from wastewater through a Typha latifolia and Thelypteris palustris phytoremediation system. Chemosphere, 241, 125018 .

Jafarpour, A., 2016. Reducing environmental impact of Sungun copper mine effluents using phytoremediation processes and its effects in the mine production scheduling. Thesis of M.Sc. Degree in Mining Engineering. Urmia University of Technology.

Jafarpour, A., Sharif, J. A., Eivazi, A., 2017. Reducing Destructive Environmental Impacts of Sungun Copper Mine Effluents with using of Phytoremediation Processes. Int. J. Pure App. Biosci, 5(2), 43-55. 
Kehrein, P., van Loosdrecht, M., Osseweijer, P., Dewulf, J., Garfi, M., Duque, J. A. P., 2020. A critical review of resource recovery from municipal wastewater treatment plants-market supply potentials, technologies and bottlenecks. Environ. Sci.: Water Res. Technol. . 6, 877-910.

Kumar, V., Pandita, S., Sharma, A., Bakshi, P., Sharma, P., Karaouzas, I., ... Cerda, A., 2019. Ecological and human health risks appraisal of metal (loid)s in agricultural soils: a review. Geology, Ecology, and Landscapes, 1-13.

Keshavarzi, A.; Tuffour, H.; Bagherzadeh, A.; Duraisamy, V., 2018. Spatial and Fractal Characterization of Soil Properties across Soil Depth in an Agricultural Field, Northeast Iran. Eurasian J. Soil Sci., 7, 35-45.

Kumar, Rajneesh, Kumar, V., Sharma, A., Singh, N., Kumar, Rakesh, Katnoria, J.K., Bhardwaj, R., Thukral, A.K., Rodrigo-Comino, J., 2019. Assessment of pollution in roadside soils by using multivariate statistical techniques and contamination indices. SN Applied Sciences, 1, 842. https://doi.org/10.1007/s42452-019-0888-3

Khan, A. H. A., Nawaz, I., Yousaf, S., Cheema, A. S., Iqbal, M., 2019. Soil amendments enhanced the growth of Nicotiana alata L. and Petunia hydrida L. by stabilizing heavy metals from wastewater. J. Environ. Manage., 242, $46-55$.

Li, C., Li, F., Wu, Z., Cheng, J. (2017). Exploring spatially varying and scale-dependent relationships between soil contamination and landscape patterns using geographically weighted regression. Appl Geogr. 82, 101-114.

Lin, S., Liu, R., Wu, M., Hu, Y., Sun, W., Shi, Z., ... Li, W., 2020. Minimizing beneficiation wastewater through internal reuse of process water in flotation circuit. J. Cleaner Prod., 245, 118898.

Mehrjardi TR, Jahromi MZ, Mahmodi S, Heidari A., 2008. Spatial distribution of groundwater quality with geostatistics (case study: Yazd-Ardakan Plain). World Appl Sci $\quad J \quad 4(1)$ :9-17. http://www.idosi.org/wasj/wasj4(1)/2.pdf

Moreno, G., Obrador, J.J., García, A., 2007. Impact of evergreen oaks on soil fertility and crop production in intercropped dehesas. Agriculture Ecosystems \& Environment 119, 270-280. https://doi.org/10.1016/j.agee.2006.07.013

Municipality Wastewater on Soil Loadings, Transfer to Wheat and Corn Grains, and Related Health Risks of Some Heavy Metals. 2013. Journal of Water and Soil. 27(3), 570-580.

Münir Öztürk; Ashraf, Muhammad; Aksoy, Ahmet; Muhammad, Sajid Aqeel Ahmad., 2015. Phytoremediation for Green Energy; Springer, 2015. 
Martín, J. F. G., Caro, M. D. C. G., Barrera, M. D. C. L., García, M. T., Barbin, D., Mateos, P. Á., 2020. Metal Accumulation by Jatropha curcas L. Adult Plants Grown on Heavy Metal-Contaminated Soil. Plants, 9(4), 418.

Mousa, A. A. K., 2009. Growth and biochemical constituents of olives as influenced by irrigation with treated industrial wastewater. J. Plant Nutr., 33(1), 1-14.

Mariet, A.-L., Pauget, B., de Vaufleury, A., Bégeot, C., Walter-Simonnet, A.-V., Gimbert, F., 2017. Using bioindicators to assess the environmental risk of past mining activities in the Vosges Mountains (France). Ecol. Indic., 75, 17-26. https://doi.org/10.1016/j.ecolind.2016.11.042

Nazir, F., Hussain, A., Fariduddin, Q., 2019. Interactive role of epibrassinolide and hydrogen peroxide in regulating stomatal physiology, root morphology, photosynthetic and growth traits in Solanum lycopersicum L. under nickel stress. Environ. Exp. Bot., 162, 479-495.

Nan, Z., Li, J., Zhang, J., Cheng, G., 2002. Cadmium and zinc interactions and their transfer in soil-crop system under actual field conditions. Sci. Total Environ., 285(1-3), 187-195.

Pérez-de-los-Reyes, C., Ortíz-Villajos, J.A.A., Navarro, F.J.G., Martín-Consuegra, S.B., Ballesta, R.J., 2015. Effects of sugar foam liming on the water-retention properties of soil. Commun. Soil Sci. Plant Anal., 46, 1299-1308. https://doi.org/10.1080/00103624.2015.1033541

Quinlan, L. D. (2001). Cubist: An informal tutorial. http://www.rulequest.com.

Quinton, J. N., and Catt, J. A., 2007. Enrichment of heavy metals in sediment resulting from soil erosion on agricultural fields. Environ. Sci. Technol., 41(10), 3495-3500.

Ryan, Veronica Anne Appleby, 2006. Phytoremediation of a high phosphorus soil by summer and winter hay harvest (M.Ss. Thesis); Agronomy and Environmental Management; Louisiana State University; Louisiana State; USA.

Rosa, J., Lemos, M. F., Crespo, D., Nunes, M., Freitas, A., Ramos, F., ... Leston, S., 2020. Integrated multitrophic aquaculture systems-Potential risks for food safety. Trends Food Sci. Technol., 96, 79-90.

Radziemska, M., Bęś, A., Gusiatin, Z. M., Cerdà, A., Mazur, Z., Jeznach, J., ... Brtnický, M., 2019. The combined effect of phytostabilization and different amendments on remediation of soils from post-military areas. Sci. Total Environ. 688, 37-45.

Rodríguez-Seijo, A., Arenas-Lago, D., Lago-Vila, M., Vega, F.A., Andrade Couce, L., 2014. Limitations for revegetation in lead/zinc minesoils (NW Spain). J Soils Sediments, 14, 785-793. https://doi.org/10.1007/s11368013-0826-8 
Rodrigo-Comino, J., Terol, E., Mora, G., Gimenez-Morera, A., Cerdà, A., 2020. Vicia sativa Roth . can reduce soil and water losses in recently planted vineyards (Vitis vinifera L.). Earth Systems and Environment In press. https://doi.org/10.1007/s41748-020-00191-5

Seyedmohammadi, J., Esmaeelnejad, L., Shabanpour, M., 2016. Spatial variation modelling of groundwater electrical conductivity using geostatistics and GIS. MESE, 2(4), 169. https://doi.org/10.1007/s40808-016-0226-3

Sharma, R.K., Agrawal, M., Marshall, F., 2007. Heavy metal contamination of soil and vegetables in suburban areas of Varanasi, India. Ecotoxicol. Environ. Saf., 66 (2): 258-266.

Shojaei, S., 2014. The use of unconventional water reclamation or destruction of the soil in arid regions (case study: Zabol). MSc thesis. University of Tehran. Page 133.

Shojaei, S. Asghari, A. Khosropour, M. Asghari, B., 2017. Evaluation of soil salinity variations by using kriging method: a case study. Stem Cell. 8(1). P 26-29.

Shojaei, S., 2016. Evaluation of pH and EC changes in wastewater application in different depths of soil. J. Res. Ecol., $4(2), 340-346$.

Saha, J. K., Selladurai, R., Coumar, M. V., Dotaniya, M. L., Kundu, S., Patra, A. K., 2017. Status of Soil Pollution in India. In Soil Pollution-An Emerging Threat to Agriculture (pp. 271-315). Springer, Singapore.

Sharma, B., and Singh, R. P., 2019. Physiological, Biochemical, Growth, and Yield Responses of Radish (Raphanus sativus L.) Plants Grown on Different Sewage Sludge-Fly Ash Mixture (SLASH) Ratios. In Waste Valorisation and Recycling (pp. 539-552). Springer, Singapore.

Singh, K.P., Mohon, D., Sinha, S., Dalwani, R., 2004. Impact assessment of treated/untreated waste water toxicants discharge by sewage treatment plants on health, agricultural, and environmental quality in waste water disposal area. Chemosphere, 55: 227-255.

Salome, C., Coll, P., Lardo, E., Villenave, C., Blanchart, E., Hinsinger, P., ... Le Cadre, E., 2014. Relevance of useinvariant soil properties to assess soil quality of vulnerable ecosystems: The case of Mediterranean vineyards. Ecol. Indic., 43, 83-93. https://doi.org/10.1016/j.ecolind.2014.02.016

Stindt, D., 2017. A generic planning approach for sustainable supply chain management - How to integrate concepts and methods to address the issues of sustainability? J. Cleaner Prod., 153, 146-163. https://doi.org/10.1016/j.jclepro.2017.03.126 
Shelton, A. M., Zhao, J. Z., Roush, R. T., 2002. Economic, ecological, food safety, and social consequences of the deployment of Bt transgenic plants. Annu. Rev. Entomol., 47(1), 845-881.

Sangwan, S. R., and Bhatia, M. P. S., 2020. Sustainable Development in Industry 4.0. In A Roadmap to Industry 4.0: Smart Production, Sharp Business and Sustainable Development (pp. 39-56). Springer, Cham.

Shi, P., Schulin, R., 2018. Erosion-induced losses of carbon, nitrogen, phosphorus and heavy metals from agricultural soils of contrasting organic matter management. Sci. Total Environ. 618, 210-218. https://doi.org/10.1016/j.scitotenv.2017.11.060

Tang, G. L., Guo, Z. C., Zhang, B., Li, X. Y., Zeng, F. J., 2019. Long-term clipping causes carbohydrate accumulation and induced transition of Alhagi sparsifolia from herbs to shrubs. Funct. Plant Biol., 46(11), 967-985.

Tai, Y., Yang, Y., Li, Z., Yang, Y., Wang, J., Zhuang, P., Zou, B., 2018. Phytoextraction of 55-year-old wastewaterirrigated soil in a $\mathrm{Zn}-\mathrm{Pb}$ mine district: effect of plant species and chelators. Environ. Technol., 39(16), 21382150.

Willey, N. (Ed.)., 2007. Phytoremediation: methods and reviews (Vol. 23). Springer Science \& Business Media.

Wolverton, B. C., and McDonald, R. C., 1979. Upgrading facultative wastewater lagoons with vascular aquatic plants. Journal (Water Pollution Control Federation), 305-313.

Wang, K., Zhang, C., Li, W., 2013. Predictive mapping of soil total nitrogen at a regional scale: a comparison between geographically weighted regression and cokriging. Appl Geogr. 42, 73-85.

Zehtabian GR, Asgari HM, Tahmouresc M., 2013. Assessment of spatial structure of groundwater quality variables based on the geostatistical simulation. Desert, 17:215-224.

https://jdesert.ut.ac.ir/article_35181_0be8db4dfaccaf59b7ae82dad1540073.pdf

Zazo, J. A., Paull, J. S., Jaffe, P. R., 2008. Influence of plants on the reduction of hexavalent chromium in wetland sediments. Environ. Pollut., 156(1), 29-35. 